\title{
Uses and Gratifications : Twitter Tetap Menjadi Primadona
}

\author{
Andhika Febi Hardina ${ }^{*}$, Irwansyah $^{2}$ \\ ${ }^{1,2}$ Ilmu Komunikasi, Universitas Indonesia \\ Jl. Margonda Raya, Pondok Cina, Kecamatan Beiji, Kota Depok, Jawa Barat \\ E-mail: ${ }^{1}$ andhika.febi@ui.ac.id, ${ }^{2}$ irwansyah09@ui.ac.id
}

Received: June 2021; Accepted: October 2021; Published: December 2021

\begin{abstract}
This study discusses the social media Twitter which is the first platform to search for the latest information or news. This is a dilator behind the large number of news or information circulating on online news portals, which are often sourced from social media Twitter. The purpose of this literature review is to see how Twitter is chosen by social media users as a place to meet their information needs. The scope of this research is in the circle of mass media communication by using Uses \& Gratifications Theory (UGT) to explain why users choose their media to complement their needs. This study uses an in-depth interview exploratory description method. The collection of data from journals or previous research is carried out based on the context and cases in which the data and information are needed in this study. In addition, this study uses an exploratory description method in-depth interviews with four respondents who use social media Twitter. Questions are given in a structured manner. The results of this study are that there is a new motivation for people to use Twitter based on the Uses \& Gratifications Theory approach, as well as the organization-public relationship approach (OPR). Empirically testing the relationship between three variables: journalists' motivation to use Twitter, work-related Twitter use, and perceived relational satisfaction with the public, were to increase their work-related activities with even higher levels of satisfaction with the public. In this result it is also added that Twitter helps to facilitate the activities of journalists by satisfying their need for information resources and work efficiency. Individual decisions to choose media in order to meet their needs do not depend on gender, age, and gender. All based on the psychological needs of each individual in general. Limitations in this study are the sample size and relatively low response rate which limits the representativeness of the population. This study only focused on journalists who used Twitter for work. Moreover, the selection of decisions on Twitter social media is based on several things such as the convenience of the Twitter social media interface, the convenience provided by Twitter, and the high level of flexibility that Twitter social media has.
\end{abstract}

Keywords: Qualitative Research, Uses and Gratification, Twitter, Social Media

doi: https://doi.org/10.51544/jlmk.v5i2.1677

(C) 2021 Jurnal Lensa Mutiara Komunikasi. This is an open access article under the CC BY-SA license Website: http://e-journal.sari-mutiara.ac.id/index.php/JLMI

http://e-journal.sari-mutiara.ac.id 


\begin{abstract}
Abstrak
Penelitian ini membahas mengenai media sosial Twitter yang menjadi platform pertama dalam pencarian informasi atau berita terkini. Hal ini dilator belakangi oleh banyaknya berita atau informasi yang beredar di portal berita online yang sering bersumber dari media sosial Twitter. Tujuan dari literature review ini adalah untuk melihat bagaimana Twitter dipilih para pengguna media sosial sebagai tempat untuk memenuhi kebutuhan informasinya. Lingkup penelitian ini adalah di lingkaran komunikasi media masa dengan menggunakan Uses \& Gratifications Theory (UGT) untuk memaparkan mengapa pengguna memilih media nya sebagai melengkapi kebutuhannya. Penelitian ini menggunakan metode deskripsi eksploratif wawancara mendalam. Pengumpulan data dari jurnal-jurnal atau penelitian terdahulu dilakukan berdasarkan konteks dan kasus yang mana data-data dan informasi tersebut dibutuhkan dalam penelitian ini. Selain itu, penelitian ini menggunakan metode deskripsi eksploratif wawancara mendalam dengan empat responden yang menggunakan media sosial Twitter. Pertanyaan diberikan secara terstruktur. Hasil dari penelitian ini adalah bahwa adanya motivasi baru orang dalam menggunakan Twitter dengan berdasarkan pendekatan Teori Uses \& Gratifications, serta organization-public relationship approach (OPR). Secara empiris menguji hubungan antara tiga variabel: jurnalis ' motivasi untuk menggunakan Twitter, penggunaan Twitter terkait pekerjaan, dan kepuasan relasional yang dirasakan dengan publik, adalah untuk meningkatkan aktivitas terkait pekerjaan mereka dengan tingkat kepuasaan yang lebih tinggi lagi dengan publik. Dalam hasil ini juga ditambahkan bahwa Twitter membantu memfasilitasi kegiatan jurnalis dengan memuaskan kebutuhan mereka akan sumber informasi dan efisiensi kerja. Keputusan individu memilih media dalam rangka memenuhi kebutuhannya tidak bergantung terhadap jenis kelamin, usia, dan gender. Semua berdasarkan terhadap kebutuhan psikologis masing-masing individu secara umum. Keterbatasan dalam penelitian ini ada pada ukuran sampel dan tingkat respons relatif rendah yang membatasi keterwakilan populasi. Penelitian ini hanya difokuskan pada jurnalis yang menggunakan Twitter terkait pekerjaan. Terlebih pemilihan keputusan terhadap media sosial Twitter, didasari oleh beberapa hal seperti kenyamanan akan interface dari media sosial Twitter, kemudahan yang diberikan Twitter, serta tingkat fleksibilitas tinggi yang dimiliki media sosial Twitter.
\end{abstract}

Keywords: Penelitian Kualitatif, Teori Uses \& Gratifications, Twitter, Media Sosial

\title{
PENDAHULUAN
}

Berdasarkan studi yang berjudul "Insta-Tweet" Appeal among Saudi Women: A Usesand-gratifications Perspective" oleh Eman Alaslani melihat bagaimana Twitter telah menciptakan cara baru dalam memberikan informasi tentang masalah sosial melalui komunikasi teman sebaya, yang berperan penting dalam perilaku pengguna. Studi ini meneliti dampak Twitter dan Instagram pada wanita Saudi, dan mencoba memahami faktor-faktor yang mendorong wanita menggunakan Instagram dan Twitter dan terlibat dalam acara sosial.

Penelitian selanjutnya yang berjudul How and Why Consumers Use Social Media: A Qualitative Study Based On User-Generated Media and Uses \& Gratifications Theory oleh Yonghwan Kim, Youngju Kim, Yuan Wang \& Na Yeon Lee. Penelitian ini mengeksplor literatur dengan analisis bagaimana motivasi dari seorang jurnalis menggunakan Twitter dan dikaitkan dengan pekerjaan mereka. Studi ini melihat dan memaparkan bagaimana hubungan antara jurnalis dan publik pada media sosial Twitter. Penelitian ini menggunakan teori Uses and Gratification dengan metode wawancara mendalam dengan jurnalis Korea. Arus pertukaran antar informasi terjadi sangat cepat di media sosial, sehingga dalam hal ini Twitter menjadi sebuah media untuk melakukan sebuah transmisi pengetahuan dan nilai kepada masyarakat (Putra \& Annissa, 2020). Hal ini yang dilakukan oleh para jurnalis tersebut.

Berdasarkan dua penelitian terdahulu, latar belakang masalah penelitian ini dikarenakan peneliti ingin melihat mengapa banyak orang yang memiliki Twitter sebagai wadah pertama untuk mencari informasi terkini. Misalnya, selama pandemi Covid-19 banyak pengguna media yang mencari berita terkini melalui media sosial Twitter dengan \#Covid19. Meskipun dalam masa pandemi, manusia yang kodratnya makhluk sosial pasti melakukan interaksi untuk berkomunikasi. Komunikasi merupakah sebuah peranan yang sangat penting dalam melakukan 
kegiatan sehari-hari, tanpa adanya sebuah komunikasi yang terjadi, maka interaksi dengan satu sama lainnya tidak berlangsung dengan baik (Sari \& Marajari, 2016).

Pada bulan November lalu, ketika seluruh Jakarta mati lampu, mereka langsung . mencari informasi di twitter dengan tagar \#Jakartablackout. Atau perkembangan isu-isu politik terkini pasti merebaknya melalui media sosial Twitter. Dibandingkan dengan menonton berita di televisi atau mengunjungi situs-situs berita online yang terpercaya. Berdasarkan hal tersebut, rumusan masalah dalam penelitian ini adalah mendeskripsikan faktor-faktor mengapa seseorang memilih Twitter sebagai tempat untuk memenuhi kebutuhan informasinya?

\section{TINJAUAN LITERATUR}

Jika merujuk pada penelitian berjudul "Insta-Tweet" Appeal among Saudi Women: A Uses-and-gratifications Perspective" oleh Eman Alaslani melihat bagaimana Twitter telah menciptakan cara baru dalam memberikan informasi tentang masalah sosial melalui komunikasi teman sebaya, yang berperan penting dalam perilaku pengguna. Studi ini meneliti dampak Twitter dan Instagram pada wanita Saudi, dan mencoba memahami faktor-faktor yang mendorong wanita menggunakan Instagram dan Twitter dan terlibat dalam acara sosial. Penelitian ini menggunakan metode kualitatif dengan teknik wawancara. Penelitian yang melibatkan tujuh wanita saudi diajukan pertanyaan dengan beberapa bahasa, yaitu dalam bahasa Inggris dan, dalam beberapa kasus, bahasa Arab. Topik wawancara ini memfokuskan pada media sosial Twitter apakah mereka mencari informasi penting, trending topik, dan meningkatkan meningkatkan kesadaran tentang hak-hak wanita. Dan pada penelitian ini sedikit membandingkan dengan media sosial Instagram. Dimana Instagram menjadi sarana kreativitas wanita saudi,media hiburan, dan selfpresentation.

Tujuan daripada penelitian ini adalah untuk mengeksplorasi kegunaan dan kepuasan dari Twitter dan Instagram dan bagaimana wanita Saudi menggunakan platform ini untuk memenuhi kebutuhan mereka di masyarakat. Peneltiian ini menggunakan teori uses and gratification untuk menentukan kegunaan dan kepuasan penggunaan Twitter dalam rangka memenuhi kebutuhan mereka. Temuan dalam penelitian ini adalah bahwa mencari informasi adalah kepuasan utama bagi pengguna Twitter. Para responden setuju bahwa Twitter merupakan platform bagi mereka untuk memperoleh atau menyebarkan informasi secara langsung.

Penggunaan tagar pada kolom pencarian twitter, pengguna dapat turut berpartisipasi dalam diskusi tentang topik yang mereka minati. Tagar "\#” atau hashtag adalah cara untuk terhubung ke kumpulan diskusi besar tentang topik tertentu dan membantu menyusun tweet tentang topik itu. Peneliti menjelaskan pengalamannya tentang bagaimana dia membagikan tagar untuk menangani masalah yang penting baginya sebagai seorang wanita Saudi. Pernyataan ini didukung oleh salah satu responden yaitu bahwa tagar Twitter adalah cara yang bagus untuk menyampaikan suaranya untuk menyelesaikan masalahnya dan berkomunikasi dengan temanteman yang bekerja di tempat yang sama.

Pada penelitian ini dapat disimpulkan bahwa seluruh responden memiliki alasan utama dalam penggunaan twitter, yaitu untuk mencari berita dan mendapatkan informasi yang mereka inginkan dan butuhkan. Media sosial twitter dengan mudahnya dapat menjangkau berbagai jenis informasi. Dalam penelitian ini, banyak responden berpendapat bahwa Twitter memungkinkan penggunanya untuk berkontribusi dalam forum diskusi melalui berbagi pendapat pribadi, minat, ideologi politik, ekonomi, atau sosial dan perspektif kehidupan yang berbeda.

Menurut Ahmad (2010) Twitter merupakan sebuah media sosial yang mendukung "pembuat kata" dan memainkan peran pengaruh politik (Ahmad, 2010). Media sosial digunakan 
oleh masyarakat untuk berkomunikasi dalam sebuah jaringan karena memiliki kelebihan untuk menjaring secara luas (Susanti \& Rahmawati, 2021). Selain itu, topik yang sedang tren menarik perhatian banyak pengguna. Penempatan hashtag membantu pengguna memahami apa yang sedang terjadi di masyarakat dan bagaimana menghadapinya.

Keterbatasan dalam penelitian ini adalah mengenai jumlah sampel yang dikumpulkan. Peneliti tidak dapat menemukan cukup banyak wanita Arab Saudi untuk berpartisipasi. Karena biasanya wanita Saudi kurang terbuka untuk membagikan pikiran mengenai topik-topik sensitif dalam masyarakat atau pribadi mereka sendiri dan masyarakat saudi umumnya konservatif. Peneliti mengusulkan untuk penelitian mendatang harus dilakukan dengan metode wawancara karena dengan wawancara akan membantu mengembangkan lebih luas dan memaparkan pemahaman yang lebih dalam tentang motivasi menggunakan Twitter.

Penelitian kedua yang berjudul Tweet this: A uses and gratifications perspective on how active Twitter use gratifies a need to connect with others oleh Gina Masullo melihat bagaimana Twitter menjadi salah satu media sosial pilihan penggunanya dalam memuaskan kebutuhannya untuk terhubung dengan pengguna lainnya. Studi ini menggunakan Uses and Gratifications yang bertujuan untuk mengeksplorasi pertanyaan-pertanyaan yang diajukan kepada responden. Menurut Tan (1995), teori uses and gratifications memaparkan bahwa berbagai media saling bersaing untuk mendapatkan perhatian khalayak. Lalu, kemudian mereka memilih media yang menurut mereka mampu memenuhi kebutuhan informasi, hiburan, dan sebuah status.

Pendekatan penggunaan dan kepuasan (U\&G) bermanfaat untuk mengeksplorasi pertanyaan-pertanyaan ini karena elemen prinsipnya mencakup kebutuhan psikologis dan sosial masyarakat serta bagaimana media dapat memuaskan kebutuhan dan motif untuk berkomunikasi ( Rubin, 2009b ). U\&G berpendapat bahwa berbagai media bersaing untuk mendapatkan perhatian pengguna, dan penonton memilih media yang memenuhi kebutuhan mereka, seperti keinginan akan informasi, hubungan emosional, dan status ( Tan, 1985 ). Menerapkan prinsipprinsip U\&G ke Twitter untuk meneliti bagaimana penggunaan Twitter berkaitan dengan kepuasan kebutuhan individu merupakan tujuan dalam penelitian ini. Studi ini pun merujuk pada pernyataan Weibull yaitu individu atau pengguna memilih untuk menggunakan media tersebut, lalu terjadinya proses kontinyutas, dimana individu kembali menggunakan media yang sama karena mendapatkan sebuah kepuasan (Weibull,1985).

Hasil dari penelitian ini bahwa bukan hanya mengeksplor dan mendapatkan informasi. Tetapi, melalui twitter kepuasan para pengguna untuk terhubung oleh satu dengan yang lainnya sangat tercukupi. Temuan dalam penelitian ini bahwa para pengguna lebih memilih menghabiskan waktu yang banyak untuk menggunakan Twitter dalam kurun waktu beberapa bulan kedepan, dibandingkan dengan chatting atau mengirim pesan kepada orang lain. Namun, keterbatasan penelitian ini bahwa mereka yang tetap menggunakan Twitter adalah orang-orang yang akhirnya memuaskan kebutuhan mereka secara pribadi untuk terhubung dengan orang lain di Twitter, tetapi tidak menjelaskan tipe orang seperti apa yang tetap menggunakan Twitter. Sehingga peneliti dalam penelitian ini berharap penelitian selanjutnya berfokus terhadap alasan orang menggunakan Twitter selama berbulan-bulan sementara yang lain meninggalkannya. Hal ini pun merupakan dampak dari lahirnya internet. Internet memberikan kontribusi yang sangat besar dalam kehidupan masyarakat dalam menunjang berbagai aktivitas (Hia \& Ginting, 2019).

Penelitian ketiga yang berjudul "Why People use social media: a uses and gratifications approach"oleh Anita Whiting dan David Williams. Temuan dalam penelitian ini mengidentiifkasi tentang sepuluh kegunaan dan kepuasan individu dalam menggunakan media sosial. Kesepuluh kegunaan ini adalah: interaksi sosial, pencarian informasi, waktu luang, 
hiburan, relaksasi, utilitas komunikasi, utilitas kenyamanan, ekspresi pendapat, berbagi informasi, dan pengawasan / pengetahuan tentang orang lain. Penelitian ini memiliki sebuah batasan yakni sama seperti penelitian pertama, yaitu keterbatasan akan sampel. Ukuran sampel pada penelitian ini masuk dalam kategori kecil. Penelitian yang menggunakan teori U\&G ini memahami dan memaparkan alasan individu menggunakan media sosial dan kepuasan apa yang mereka dapatkan.

Batasan dalam penelitian ini adalah ukuran sampel yang kecil. Implikasi penelitiannya adalah bahwa teori kegunaan dan kepuasan memiliki relevansi khusus dengan media sosial dan harus lebih ditekankan. Teori kegunaan dan kepuasan membantu menjelaskan banyak dan beragam alasan mengapa konsumen menggunakan media sosial.

Perbedaan motivasi mengapa individu atau pengguna memilih menggunakan media sosial dibandingkan dengan kedua penelitian sebelumnya adalah ditemukannya Surveilans atau mengetahui tentang orang lain . Disebutkan dalam penelitian ini bahwa $32 \%$ responden dalam konteks ini sebagai pengamat perilaku orang lain atau yang disebut stalker. Mereka "mematamatai orang", mereka "melihat sesuatu tentang orang lain tanpa mereka sadar". Dan mereka berpendapat bahwa kebanyakan dari mereka ingin mengetahui apa yang dilakukan orang lain dan mereka pun berusaha mengikuti orang lain. Hal ini didukung oleh penelitian dari studi Kaye \& Johnson (2002) mengenai motivasi penggunaan web untuk faktor informasi politik.

Hasil daripada penelitian ini mengidentifikasi sepuluh kegunaan dan kepuasan dalam menggunakan media sosial. Studi saat ini mengidentifikasi sepuluh kegunaan dan kepuasan dalam menggunakan media sosial. Sepuluh kegunaan dan kepuasan yang ditemukan dalam penelitian ini adalah interaksi sosial ( 88 persen), pencarian informasi ( 80 persen), menghabiskan waktu (76 persen), hiburan (64 persen), relaksasi (60 persen), utilitas komunikasi (56 persen),mengekspresikan pendapat (56 persen), utilitas kenyamanan (52 persen), berbagi informasi (40 persen), serta pengawasan orang lain (20 persen).

Penelitian keempat yang berjudul How and Why Consumers Use Social Media: A Qualitative Study Based On User-Generated Media and Uses \& Gratifications Theory oleh Yonghwan Kim,dkk. Penelitian ini mengeksplor literatur dengan analisis bagaimana motivasi dari seorang jurnalis menggunakan Twitter dan dikaitkan dengan pekerjaan mereka. Studi ini melihat dan memaparkan bagaimana hubungan antara jurnalis dan publik pada media sosial Twitter. Penelitian ini menggunakan teori Uses and Gratifications sama seperti ketiga penelitian lainnya dengan metode wawancara mendalam dengan jurnalis Korea.

Menurut Katz (dalam Rubin, 2009) bahwa penggunaan dan pendekatan U\&G sangat relevan untuk melihat hubungan antara jurnalis dan publik di ranah media sosial Tiwtter. Teori ini memaparkan bagaimana seseorang inidividu menggunakan media untuk memuaskan kebutuhan mereka dan juga melihat perbedaan pola penggunaan media. Menurut Chen (2011) berpendapat bahwa banyak individu menghabiskan waktu di media sosial seperti Twitter, berarti individu tersebut memenuhi kebutuhannya.

Studi ini memiliki sebuah asumsi yang berfokus terhadap jurnalis yang memiliki kebutuhan jurnalistiknya dengan menunjukkan pola penggunaan media sosial Twitter terkait dengan pekerjaannya. Sehingga dalam penelitian ini diharapkan bahwa jurnalis memiliki alasan tersendiri secara khusus dalam penggunaan media sosial Twitter yang berbeda dari para 
pengguna biasa lainnya (non-jurnalis). Hal ini didukung pernyataan bahwa postingan di media sosial twitter semakin banyak digunakan sebagai sumber informasi yang cepat dan terkini bagi jurnalis dan berita mereka (Moody, Cohen, \& Fournon, 2013 ; Waters, Tindall, \& Morton, 2010). Misalnya, seseorang memberikan berita melalui Twitter jika terjadi sesuatu bencana alam di suatu daerah. Kemudian, saksi yang melihat atau merasakan bencana alam tersebut dapat segera men-tweet informasi secara langsung. Hal ini dapat menjadi sumber berita yang berharga bagi jurnalis dan publik. Selanjutnya, jurnalis mengikuti pengguna Twitter yang dapat memberikan informasi yang mungkin berkontribusi pada liputan topik tertentu (Hill, 2010 ). Misalnya, banyak jurnalis lifestyle mengikuti dokter gizi atau influencer yang menerapkan pola hidup sehat untuk memanfaatkan tweet mereka dalam liputan lifestyle. Hal ini dapat memberikan informasi yang sulit diperoleh jurnalis melalui pendekatan tradisional (Deprez et al., 2013).

Selain itu, jurnalis dapat menggunakan Twitter sebagai cara untuk berinteraksi dengan publik atau rekan sesama jurnalis. Misalnya, mereka (jurnalis) terlibat dalam sebuah diskusi dengan pengguna lainnya. Dalam hal ini Twitter berperan untuk membuat koneksi dengan audiens mereka (Steinberg, 2009 ) dan mengoptimalkan hubungan dengan mereka melalui berbagai pesan relasional (Lin \& Peña, 2011 ). Sebagai dampak kontinyuitas, Twitter dapat menjadi alat yang berguna untuk diskusi selanjutnya dengan publik dengan memungkinkan jurnalis untuk menyoroti dan berbagi materi relevan yang dirilis oleh sumber lain untuk memberikan pemahaman yang komprehensif tentang suatu masalah atau peristiwa saat terungkap (Bruns, Burgess, Crawford, \& Shaw, 2012 ).

Dalam penelitian ini disebutkan bahwa dalam beberapa tahun ini, selain jurnalis, organisasi media pun banyak yang menggunakan platform jejaring sosial (Messner et al., 2011). Mereka menggunakan jejaring sosial untuk menyebarkan informasi, mempromosikan organaisasi atau sebuah program, serta berinteraksi maupun mencari atensi dari publik (Deprez, Mechant, \& Hoebeke, 2013). Temuan sebelumnya menunjukkan bahwa hal yang mendorong antara organisasi media dengan publik dalam media sosial Twitter adalah pada fitur Twitter yang bersifat interaktif.

Hasil dari peneltiian ini berdasarkan pendekatan teori U\&G dan organization-public relationship approach (OPR), secara empiris menguji hubungan antara tiga variabel: jurnalis ' motivasi untuk menggunakan Twitter, penggunaan Twitter terkait pekerjaan, dan kepuasan relasional yang dirasakan dengan publik, adalah untuk meningkatkan aktivitas terkait pekerjaan mereka dengan tingkat kepuasaan yang lebih tinggi lagi dengan publik. Dalam hasil ini juga ditambahkan bahwa Twitter membantu memfasilitasi kegiatan jurnalis dengan memuaskan kebutuhan mereka akan sumber informasi dan efisiensi kerja.

Keterbatasan dalam penelitian ini ada pada ukuran sampel dan tingkat respons relatif rendah yang membatasi keterwakilan populasi. Penelitian ini hanya difokuskan pada jurnalis yang menggunakan Twitter terkait pekerjaan. Terlebih banyak organisasi berita memiliki kebijakan yang mendorong jurnalis menggunakan media sosial untuk mempromosikan konten berita mereka dan berinteraksi dengan audiens mereka. Sehingga hal tersebut dapat mempengaruhi motif jurnalis dalam aktivitas penggunaan media sosial Twitter. Dengan demikian, diharapkan pada penelitian selanjutnya dapat membahas pertimbangan ini. Selain itu, sebagai tambahan, penelitian ini berfokus pada konteks jurnalis korea, sehingga perbedaan budaya dapat menghasilkan perspektif yang berbeda.

Dari keempat penelitian diatas, bahwa semuanya menggunakan pendekatan Teori Uses and Gratifications dalam melihat fenomena-fenomena yang terjadi. Sehingga lebih jelasnya akan 
dipaparkan sedikit penjelasan teori U\&G. Menurut Dainton Katz, Blumler\& Gurevitch (dalam Dainton, 2018:296), Uses and Gratifications Theory memiliki tiga asumsi dasar, antara lain sebagai berikut.

a. Audiens secara aktif menggunakan berbagai media untuk memenuhi kebetuhannya.

b. Komunikasi massa bukanlah sesuatu yang terjadi kepada kita; media tidak melakukan apapun.

c. Media bersaing satu dengan yang lainnya dalam rangka memnuhi dan memuaskan kebuthan pribadi audiensnya.

Dengan kata lain bahwa teori uses and gratification menyatakan bahwa audiens memiliki banyak opsi yang sengaja mereka pilih dalam rangka memenuhi kebutuhan pribadi.

Terdapat beberapa tipologi dari Teori Uses and Gratifications (Griffin, 2018: 350-351)

a. Passing Time: Menghabiskan atau mengisi waktu luang kita

b. Companionship: Berkumpul dengan rekan-rekan untuk menonton hal yang sama-sama digemari

c. Escape: Untuk melarikan diri dari tekanan dan pikiran

d. Enjoyment: Menemukan dan menikmati acara Televisi yang disajikan.

e. Social Interaction: Menonton TV memberikan dasar untuk terhubung dengan orang lain.

f. Relaxation: Setelah bekerja seharian, banyak orang berpendapat bahwa dengan menonton TV pikiran menjadi lebih santai dan memiliki cara lain untuk tertidur. Dalam konteks ini, media digunakan sebagai tempat relaksasi.

g. Information: TV sebagai tempat untuk mencari informasi terkini

h. Excitement: Individu atau pengguna akan lebih menyukai hal-hal sensasional. Seperti menonton hal hal yang berbau konflik dan kekerasan

\section{METODE PENELITIAN}

Penelitian ini menggunakan metode deskripsi eksploratif wawancara mendalam. Hal ini menjadi pertimbangan karena berdasarkan penelitian-penelitian terdahulu, disarankan metode wawancara untuk mendapatkan hasil yang lebih mendalam dan luas. Tujuan daripada studi ini adalah untuk memaparkan keadaan atau fenomena yang dimaksudkan dengan tidak menguji sebuah hipotesis, tetapi hanya menggambarkan apa adanya kondisi dan keadaan secara riil (Arikunto, 2002).

Wawancara diberikan kepada empat responden dengan kriteria dua laki-laki dan dua perempuan dengan kriteria usia 23-25 tahun dan pengguna media sosial Twitter. Teknik pengumpulan data berdasarkan wawancara mendalam secara terstruktur melalui telepon dan secara langsung. Pertanyaan-pertanyaan yang diajukan berdasarkan pengembangan dari konseptualisasi dan metode penarikan kesimpulan dengan pengolahan data transkrip wawancara.

Metode penelitian pada naskah artikel menjelaskan jenis penelitian, subjek dan objek penelitian, waktu dan lokasi penelitian, instrumen penelitian, cara pengambilan sampel, pengumpulan data, dan analisis data.

\section{HASIL DAN PEMBAHASAN}

Berdasarkan hasil penelitian melalui wawancara mendalam dan penelitian-penelitian terdahulu bahwa dapat dikatakan bahwa Teori Uses and Gratifications secara keseluruhan mampu menggambarkan motivasi seseorang memilih media untuk melengkapi kebutuhannya. Banyak pengguna media sosial memilih Twitter karena Twitter salah satu media sosial yang 
memiliki interface lebih mudah digunakan dan lebih komunikatif. Sifat twitter, dengan karakter yang terbatas sebanyak 140, dijelaskan bahwa jenis motivasi dan kepuasan yang dicari pengguna yaitu berbagi informasi dan interaksi sosial paling prediktif dari niat yang diungkapkan untuk terus menggunakan Twitter (Liu, Cheung, dan Lee, 2010). Demikian pula, Johnson dan Yang (2009) menemukan bahwa motivasi berbagi informasi cukup berkorelasi dengan waktu yang dihabiskan di situs mingguan dan frekuensi kunjungan per minggu.

Dengan penggunaan tagar atau hashtag dalam kolom pencarian dapat mempermudah pengguna media Twitter untuk menggali informasi lebih cepat dan detail. Selain itu, seluruh keempat responden mangatakan bahwa media sosial Twitter, jika dibandingkan dengan portal berita online lebih cepat dalam penyebaran informasinya. Mereka pun bisa secara langsung melakukan diskusi dan tanggapan terhadap situasi yang terjadi. Selain itu, banyak portal berita online seperti CNN atau Kompas.com telah masuk ke dalam jaring media sosial Twitter. Dan lebih mudah diaksesnya melalui Twitter dibangkan masuk ke laman portal tersebut. Ketika mencari informasi yang sedang terjadi disekitar kita, seperti terjadinya Jakarta Blackout pada bulan November lalu, perkembangan Covid-19, atau isu-isu dunia politik, Twitter menjadi platform yang menyajikan informasi yang sangat cepat dan isu-isu terkini. Sehingga, banyak pengguna media sosial selalu beralih ke Twitter.

Pada penelitian Insta-Tweet" Appeal among Saudi Women: A Uses-and-gratifications Perspective" oleh Eman Alaslani melihat bagaimana Twitter telah menciptakan cara baru dalam memahami faktor-faktor yang mendorong wanita Saudi menggunakan Twitter untuk memenuhi kebutuhan di dalam masyarakat; meningkatkan kesadaran tentang hak-hak wanita. Pada penelitian ini memfokuskan terhadap gender wanita saja.

Namun, ini menjadi tolak ukur pengukuran apakah Twitter hanya berdasarkan gender kaum hawa saja atau tidak. Ternyata berdasarkan hasil wawancara mendalam dengan keempat responden dapat dikatakan bahwa banyak yang menggunakan Twitter bukan hanya untuk mencari isu-isu kegenderan terkait hak-hak wanita, mapun LGBT+. Namun, banyak sekali komunitas-komunitas atau kelompok-kelompok sosial lainnya yang tersebar dalam jaringan Twitter.

Jika pada penelitian kedua yang berjudul "Tweet this: A uses and gratifications perspective on how active Twitter use gratifies a need to connect with others" oleh Gina Masullo melihat bagaimana Twitter menjadi salah satu media sosial pilihan penggunanya dalam memuaskan kebutuhannya untuk terhubung dengan pengguna lainnya. Disebutkan bahwa media sosial twitter tidak bisa menawarkan atau menumbuhkan rasa kebersamaan komunitas atau kelompok. Namun, pada kenyataan lapangannya. Seluruh responden menjawab jika sebuah isu-isu k-pop, kegenderan, menggerakan hak-hak wanita, maupun LGBT+, Twitter merupakan wadah yang tepat untuk memberikan rasa kebersmaan secara psikologis.

Para anggota penggerak atau komunitas yang tersebar di beberapa wilayah dapat berkomunikasi atau melakukan online campaign secara terpusat melalui tagar/hashtag di Twitter. Mereka merasa bahwa adanya rasa kedekatan dan saling mendukung satu sama lain walaupun terpisah jarak dan hanya didekatkan melalui media sosial Twitter (Celvin Moniaga Sipahutar, Ana Fitriana Poerana, 2017). Bukan hanya sebagai sarana menggali informasi, tetapi Twitter telah menghubungkan antar penggunanya melalui kedekatan interpersonal, karena memiliki perasaan terkait identitas yang sama. Salah satu responden dari hasil wawancara mendalam menambahkan"Sense of belonging to one community bisa banget didapetin dari berjaring sosial lewat Twitter". 
Selain itu, dari aplikasi Twitter sendiri dirasa memiliki interface yang baik, kemudahan dalam mengakses, dan fitur-fitur yang menunjang sehingga terciptanya sebuah suasana interaktif di dalam media sosial Twitter. Sebagai tambahan, konten-konten pada media sosial Twitter pun sangat beragam, dari hal-hal ringan hingga topik yang dirasa lebih serius. Jadi, para pengguna mendapatkan kenyamanan dan tingkat fleksibilitas yang tinggi dalam menggunakan media sosial Twitter. Dengan kata lain, informasi apa yang dibutuhkan oleh indiividu, Twitter merupakan jawaban yang tepat.

JIka kita melihat dan memfokuskan kepada permasalahan jurnalisitik atau berita terkini, Twitter telah menjadi wadah dalam hal ini. Misalnya di Indonesia, Najwa Shihab merupakan seorang jurnalis senior yang cukup aktif di media sosial Twitter. Tidak jarang dia sering berdiskusi atau berintekasi dengan publik yang menimbulkan efek keberlanjutan dan berbagi berbagi materi relevan yang dirilis oleh sumber lain untuk memberikan pemahaman yang komprehensif tentang suatu masalah atau peristiwa saat terungkap (Bruns, Burgess, Crawford, \& Shaw, 2012 ).

\section{KESIMPULAN}

Berdasarkan hasil penelitian kualitatif ini dengan pendekatan deskriptif eksplorasi, peneliti menyimpulkan bahwa teori Uses and Gratifications dalam penelitian ini mampu menggambarkan permasalahan yang diangkat. Teori U\&G sangat relevan untuk mendeskripsikan motivasi apa yang dimiliki oleh masing-masing individu memilih media apa yang akan diambilnya dalam memenuhi kebutuhan pribadi mereka. Keputusan individu memilih media dalam rangka memenuhi kebutuhannya tidak bergantung terhadap jenis kelamin, usia, dan gender. Semua kembali terhadap kebutuhan psikologis masing-masing individu secara umum.

Pemilihan keputusan terhadap media sosial Twitter, didasari oleh beberapa hal seperti kenyamanan akan interface dari media sosial Twitter, kemudahan yang diberikan Twitter, serta tingkat fleksibilitas tinggi yang dimiliki media sosial Twitter.

Namun, penelitian ini hanya mampu melengkapi beberapa pernyataan yang belum diajukan atau penyempurnaan dari penelitian terdahulunya (pada sub-bab temuan penelitian) di dalam hasil diskusi. Keterbatasan penelitian terletak pada waktu dan sampel. Sehingga penelitian ini tidak bisa memfokuskan bagaimana perkembangan atau perubahan motivasi seseorang dalam menggunakan media sosial twitter secara berkala dan sampel yang diambil tidak mewakilkan secara keseluruhan.

Penelitian ini memiliki beberapa saran yang dapat disampaikan, antara lain sebagai berikut.

1. Kepada peneliti yang selanjutnya akan meneliti tentang fenomena yang berkaitan dengan teori uses and gratifications disarankan untuk menggali lebih dalam konsep-konsep yang belum dapat dieksplorasi dengan temuan-temuan yang lebih baru.

2. Kepada pihak portal-portal berita di Indonesia untuk selalu mengembangkan portal beritanya tidak hanya melalui akun media sosial Twitter. Namun, juga beberapa platform lainnya. 


\section{DAFTAR PUSTAKA}

Alaslani, E. (2019). “ Insta-Tweet” Appeal among Saudi Women: A Uses-and-gratifications Perspective.

Alhabash, S., \& Ma, M. (2017). A Tale of Four Platforms: Motivations and Uses of Facebook, Twitter, Instagram, and Snapchat Among College Students? Social Media and Society, 3(1). https://doi.org/10.1177/2056305117691544

Bessiere, K., Kiesler, S., Kraut, R. E., \& Boneva, B. (2008) Effects of Internet use and social resources on changes in depression, Information, Communication Society 11 (1).

Bruns, A., Burgess, J., Crawford, K., \& Shaw, F. (2012). \#qldfloods and @QPSMedia: Crisis communication on Twitter in the 2011 south east Queensland floods. Brisbane, Australia: ARC Centre of Excellence for Creative Industries and Innovation.

Celvin Moniaga Sipahutar, Ana Fitriana Poerana, N. (2017). Pengalaman Komunikasi Curhat Anonim Bagi Followers @18AUTOBASE Di Twitter. Jurnal Lensa Mutiara Komunikasi, 4(2), 56-74.

Chen, G. M. (2011). Tweet this: A uses and gratifications perspective on how active Twitter use gratifies a need to connect with others. Computers in Human Behavior, 27(2), 755-762. https://doi.org/10.1016/j.chb.2010.10.023

Deprez, A., Mechant, P., \& Hoebeke, T. (2013). Social media and Flemish sports reporters: A multimethod analysis of Twitter use as journalistic tool. International Journal of Sport Communication, 6, 107-119.

Griffin, E., Ledbetter, A., \& Sparks, G. G. (2018). A First Look At Communication Theory, 10th Edition. In McGraw-Hill. http://www.amazon.com/First-Look-CommunicationTheory/dp/0072291532

Hia, N., \& Ginting, S. (2019). Pengaruh Internet Terhadap Prestasi Belajar Mahasiswa Fakultas Ekonomi Dan Ilmu Sosial Universitas Sari Mutiara Indonesia Kota Medan. Jurnal Lensa Mutiara Komunikasi, 2(1), 61-67.

Katz, E., Blumler, J., \& Gurevitch, M. (1974). Utilization of mass communication by the individual. In J. G. Blumler \& E. Katz (Eds.), The uses of mass communications: Current perspectives on gratifications research (pp. 19-32). Beverly Hills, CA: Sage.

Kim, Y., Kim, Y., Wang, Y., \& Lee, N. Y. (2016). Uses and Gratifications, Journalists' Twitter Use, and Relational Satisfaction with the Public. Journal of Broadcasting and Electronic Media, 60(3), 503-526. https://doi.org/10.1080/08838151.2016.1164171

Liu, I. L. B., Cheung, C. M. K., \& Lee, M. K. O. (2010). Understanding twitter usage: What drive people continue to tweet. PACIS 2010 - 14th Pacific Asia Conference on Information Systems, January, 928-939.

Moody M, Cohen L, Fournon C (2013) Negativity in a Twitter Age: How Politicians are Adapting to Social Media. J Mass Communicat Journalism 3: 151. doi:10.4172/21657912.1000151

Putra, R. W., \& Annissa, J. (2020). Visualisasi Makna Politik Pada E-Comic. Jurnal Lensa Mutiara Komunikasi.

Sari, S. N., \& Marajari, M. R. (2016). Efektivitas Komunikasi Interpersonal Universitas Sari Mutiara Indonesia. Lensa Mutiara Komunikasi, 36-48.

Susanti, S., \& Rahmawati, T. S. (2021). Humor dan Covid-19: Makna Pesan dalam Akun Instagram @t_faturohman. Jurnal Lensa Mutiara Komunikasi, 5(1), 1-9. https://doi.org/10.51544/jlmk.v5i1.1785 